\title{
Implementation of GIS Application for Water Company Needs
}

\begin{abstract}
The process of designing and implementing industrial models (or GIS) for underground utility infrastructure (UUI) includes a number of activities related to the analysis of source data to identify objects, pre-processing the initial data, creating spatial database and development of relevant graphic (maps) and text (registers) products.

Nowadays, every organization needs to be flexible and able to respond in a timely and adequate manner to the changes that occur in a complex and dynamic external environment. This is the reason why the paper proposes an approach for the design and development of a geoinformation system (GIS), through the capabilities of modern software for a part of the water supply and sewerage network for the needs of Water Supply and Sewerage Berkovitsa LTD.

The purpose of the paper and GIS for maintaining data on UUI is to provide access to digital data for underground utility infrastructure and their characteristics, as well as to assist in the easy creation of references to underground utility infrastructure data in digital and graphic form.
\end{abstract}

Keywords: GIS, underground utility infrastructure and facilities, industrial models, geospatial data, spatial registration of utility infrastructure data

Received: 4 July 2020; accepted: 29 July 2020

(C) 2020 Authors. This is an open access publication, which can be used, distributed and reproduced in any medium according to the Creative Commons CC-BY 4.0 License.

1 University of Architecture, Civil Engineering and Geodesy, Geodesy and Geoinformatics Department, Sofia, Bulgaria, email: kmikrenska_fgs@uacg.bg

ORCID ID: https://orcid.org/0000-0002-7054-1799

2 Water Supply and Sewerage Berkovitsa LTD, Berkovitsa, Bulgaria, email: radoslav979@abv.bg 


\section{Introduction}

Within the territory of a given country, and mainly in the big cities, there are different types of overground and underground utility infrastructure. Different companies provide services, such as: electricity, water, gas, television, and internet. In our daily lives, the lack of any service is a considerable inconvenience and shows the importance of good condition, proper functioning and accessibility to the network through which these services are distributed. The speed of changes in the underground utility infrastructure is also important to society, the correction of breakdowns, the prevention of unauthorized access and their safety [1].

A major problem faced by water infrastructure is the lack of effective tools for managing and maintaining these ageing assets. Significant benefits can be achieved through the implementation of a geographic information system (GIS) to understand the spatial relationships between the parameters [2].

The main problem facing urban areas is related to the management of the territory, as it does not obtain up-to-date and adequate information on underground networks and facilities. In addition, there is no modern way, based on the current technologies, for communication between the municipality and the operating companies. All this leads to chaotic work with underground infrastructure, lack of adequate planning and, as a result, a waste of energy and resources and a poor quality of services for citizens. The lack of reliable and complete information is also identified as an obstacle to quick investment decision making.

The main objective of the geoinformation system is to improve the opportunities for access to underground communications information, reduce the risks in maintaining and managing infrastructure and networks, as well as urban planning and development activities.

The purpose of the paper and GIS for maintaining data on underground utility infrastructure (UUI) is to provide access to digital data for underground utility infrastructure and their characteristics, as well as to assist in the easy creation of references to UUI data in digital and graphic form.

According to [2] significant benefits can be achieved through the implementation of geographic information system (GIS) to understand spatial relationships between the affecting parameters. The aim is better understanding and visualizing data in GIS related to underground infrastructure.

Many authors have proposed various solutions for data structuring and implementation of GIS to deal with different tasks. More information can be found in [2-6].

GIS provides specialized functionality for editing and referencing cadastral and UUI data. GIS for the purposes of water supply and sewerage (WSS) companies should integrate the following basic data types:

- full geographical representation of the WSS networks - all objects (pipes, shafts, taps, facilities, etc.) are represented by their geometry; 
- complete set of engineering information for networks - lengths, slopes, elevations, sizes and types of cross sections, materials, hydraulic characteristics, etc.;

- full geographical representation of topography - all objects (parcels, buildings, streets, sidewalks, squares, etc.) are represented by geometric objects with real sizes and shapes;

- register of operational events, repair activities and reconstructions linked to the objects of the WSS networks;

- client databases linked to the objects of the WSS networks.

The implementation of GIS leads to improved quality of management, significantly reducing the time for analysis and decision-making. The proper data structure and automated processes for exchanging information between different units - technical departments, operating structures, accounting and senior management - in practice minimize the potential for errors or misuse of information. The quality and accuracy of information is strictly maintained through the capabilities of the software environment and through an administrative system for managing the flow of data between units in the water supply and sewerage companies.

Once the data are imported in GIS, later they can be used in transition to 3D Cadastre [4, 6] by following the standards given in [7].

The lack of reliable and easily accessible digital information about the existing WSS infrastructure is one of the most serious problems in the management of water supply and sewerage companies in Bulgaria. From the wrong data to design, to the inability to analyze and manage existing networks, to the chaotic and often ineffective technical measures, data status is the root of all problems. In most cases, WSS operators have a limited amount and degree of reliability of information arrays, mainly on paper with disputed quality and lack of any guarantee of accuracy [8].

The main problems can be summarized as follows:

- the data about the networks are on paper - there is no possibility for adequate verification of accuracy and updating of the information in practice;

- the paper data are of an uncertain origin - often the WSS companies have parts of projects with unknown status (conceptual decisions, parts of executives, etc.), old operational registers in text form, etc., which makes it impossible to check the connectivity and correctness of the networks;

- in some cases, the available data is digitized, but often without a professional methodology or engineering validation for the accuracy of the information;

- generally, operation and asset status registers are not maintained;

- in general, there is no system for managing data on networks - the information is stored randomly in different administrative units without procedures for exchange and quality control. 


\section{Model Design of Water Supply and Sewerage Infrastructure in CAD/GIS Environment}

There are a lot of definitions of GIS. Abstracting from the various GIS definitions, geographic (geospatial) data is a key component in all definitions. There are numerous different areas in which GIS is applied - from information security to the tasks of regional government and forecasting the consequences of global emergencies. The current period of development of GIS is characterized by the transition from theoretical research to the widespread use of geoinformation technologies for solving various problems [9]. For the regional governance purposes, one of the aspects of GIS implementation is the assessment of projects in the construction and reconstruction of the engineering infrastructure, modern spatial plans and projects for the socio-economic development of different territories. In order to present the capabilities of modern software applications for the design of geoinformation systems, the development of a model of WSS infrastructure is presented. The proposed solution also serves to create specialized maps and registers of existing WSSN.

Specialized maps and registers for UUI are designed to determine the spatial position of all networks and facilities. The main technical characteristics of the specialized objects are shown. Companies which services are delivered to consumers operate most of the networks. It is important for companies to provide the quality services, to ensure continuous access to these services, to rectify quickly damages and to prevent unauthorized access. In highly urbanized areas, there is a great need for accurate and up-to-date information about UUI. This information is applicable to: designing development plans (general and detailed); preliminary studies for the preparation of investment projects; research and design for construction of new UNF; reconstruction of existing networks and facilities; when maintaining and operating a UNF; design grading plans; landscaping projects in settlements; analyzes providing for extension and necessary changes to the UUI.

With the development of information and communication technologies, maps and registers are produced directly in digital form [3]. Modeling the collected object data, the final product is specialized digital model (industrial). The data is stored in databases from where various information can be extracted.

The designed model refers to a part of the WSS network of Berkovitsa town.

Berkovitsa is a city located in northwestern Bulgaria, Montana District. It is situated $23 \mathrm{~km}$ southwest of the city of Montana and $80 \mathrm{~km}$ north of the capital Sofia. Berkovitsa is the administrative and economic center of the municipality of Berkovitsa. The technology used includes the analysis and structuring of the available data, design of database and industrial model, creation of schemes and registers of the objects from the WSS networks.

The available initial input data are as follows: cadastral map and register; partial surveying measurements of existing WSS networks; maps and documents on paper, owned by the Water supply and Sewerage, Berkovitsa LTD. 


\subsection{Database}

WSS company provided data for the consumers of the plumbing services in hard copy (book of collectors) about: Account number; Account holder - name and surname for individuals and company name for legal entities; Town or village; Street name, property number, block number, etc; Year of water meter placement for each individual lot number; Others. Old maps of WSS networks provide data about: Water supply - location, diameter, material and length; Water taps - location; Fire hydrants - location; Sewer pipes - location, diameter and material; Sewerage inspection shafts - location, elevation, elevation bottom; Others.

Source data were analyzed, synthesized and used to create a geospatial (industrial) model. The designed model consists of two main packages - "Water supply network" and "Sewerage network". A part of the UML Class Diagram of the water supply network is shown in Figure 1.

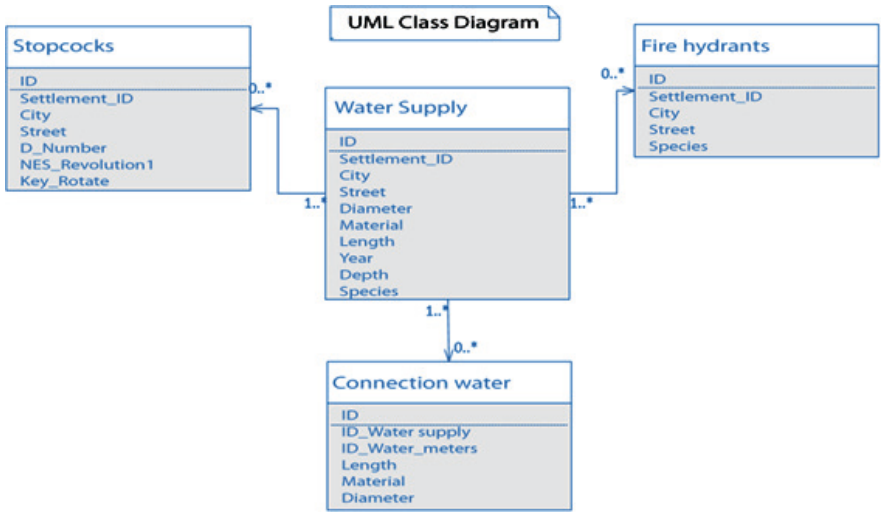

Fig. 1. Water supply network schema

The content of the created topics (package) and feature classes is described in Table 1. Additional tables, which are code lists (domains) - property type, usage type and territory type, are also included.

Table 1. Topics, feature classes, statistics and type

\begin{tabular}{||l|l|c|c|l||}
\hline \hline \multirow{2}{*}{ Topic/package } & \multicolumn{1}{|c|}{$\begin{array}{c}\text { Table name } \\
\text { (feature class) }\end{array}$} & $\begin{array}{c}\text { Imported } \\
\text { objects }\end{array}$ & $\begin{array}{c}\text { Number } \\
\text { of attributes }\end{array}$ & \multicolumn{1}{|c||}{ Feature class type } \\
\hline \hline \multirow{4}{*}{$\begin{array}{l}\text { Water supply } \\
\text { network }\end{array}$} & water meters & 786 & 12 & point \\
\cline { 2 - 6 } & stopcocks & 100 & 7 & point \\
\cline { 2 - 6 } & fire hydrants & 32 & 5 & point \\
\cline { 2 - 6 } & water supply & 263 & 12 & linestring \\
\cline { 2 - 6 } & connection water & 907 & 6 & linestring \\
\hline \multirow{2}{*}{ Sewerage network } & inspection shafts & 215 & 6 & point \\
\cline { 2 - 6 } & sewerage & 131 & 7 & linestring \\
\hline Cadastre & cadastral data & 1823 & 10 & polygon \\
\hline
\end{tabular}




\subsection{Design of Industrial Model}

Two Autodesk products are used to design the industrial model - Infrastructure Administrator and AutoCAD Map 3D. The industrial model allows the user to manage a specialized database containing geometry and attribute data. The feature class type of designed packages "Water supply network" and "Sewage network" are given in Table 1. The attributes of water supply and inspection shaft classes are shown in Figure 2 and 3.

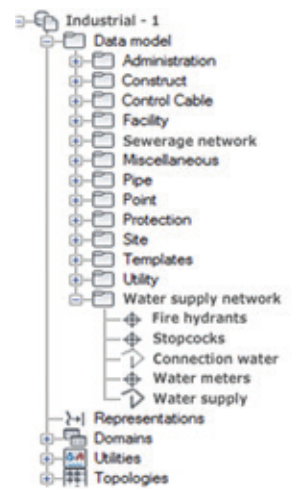

\begin{tabular}{|c|c|c|c|c|c|c|}
\hline Name & Cosption & Une & Dota Type & Length/Prec. & Scale & Opto \\
\hline FID & FID & & Number & 18 & & Folve \\
\hline GEOM & Geomety & & Geometry & & & True \\
\hline LENGTH & Length of the ine & moter & Number & 20 & 8 & True \\
\hline 10 & w & & Number & 10 & & True \\
\hline Setviement_ID & Settlement_10 & & NVarchar2 & 20 & & True \\
\hline crTY & City & & NVarchar2 & 20 & & True \\
\hline STREET & Street & & Narchar2 & 20 & & True \\
\hline DLAMETER & Dismeter & & NWarchar2 & 10 & & True \\
\hline MATERIAL & Matenial & & NWarchar2 & 20 & & True \\
\hline YEAR & Year & & NVarchar2 & 10 & & True \\
\hline DEPTH & Desth & & Norchar2 & 10 & & True \\
\hline SPECIES & Species & & NVarchar2 & 20 & & True \\
\hline
\end{tabular}

Fig. 2. Water supply class attributes

\begin{tabular}{|c|c|c|c|c|c|c|c|}
\hline \multirow{5}{*}{$\begin{array}{l}\text { Cि Industrial - } 1 \\
0 \text { Dxta model } \\
\text { Administrotion }\end{array}$} & Name & Costion & Une & Dxa Type & Length/Prec. & Scale & Ostor \\
\hline & FID & FID & & Nenber & 18 & & Folve \\
\hline & GEOM & Geomety & & Geomety & & & Tne \\
\hline & ORIENTATION & Onertation & degree dockwise & Number & 6 & 3 & Folse \\
\hline & $z$ & $z$ & & Number & 20 & 8 & True \\
\hline Sewerage network & QUAUTY & Quality of the point & & Number & 10 & & True \\
\hline Le Inspection shafts & TB_POINTNUMBER & Poirt Number & & Varchar2 & 64 & & True \\
\hline 10 Miscelsneous & 10 & id & & Nember & 10 & & True \\
\hline -DP Pee & Settlement_ID & Settlement_ID & & Narchar2 & 20 & & True \\
\hline Poirt & City & City & & Norchar2 & 20 & & True \\
\hline D secection & STREET & Street & & Narchar2 & 20 & & True \\
\hline - Temolates & ELEVATION_T & Bevetion_T & & Norchar2 & 20 & & True \\
\hline $\begin{array}{l}9-\bigcirc \text { Uity } \\
\text { Water supply network }\end{array}$ & ELEVATION_D & Bevasion_D & & Narchar2 & 20 & & True \\
\hline 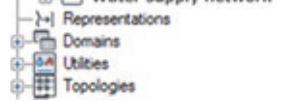 & & & & & & & \\
\hline
\end{tabular}

Fig. 3. Inspection shaft class attributes

\section{GIS Application for the WSS Company}

\subsection{Processing of Available Geodata}

The analysis of available geodata shows that they need to be edited. In order to be compatible for post-processing in AutoCAD MAP 3D, a number of preliminary activities need to be made, such as: Combining the description texts into objects 
and objects into one layer; Spatial objects are in layers corresponding to their names; Line types correspond to the object class; Conversion of arcs and lines to polyline; Rename of layers names; Creation of theme layers and layer filters; Detection and editing map errors - duplicate lines, objects, undershoots and etc. Preparation for topologies; data import of land surveying measurements for a newly constructed mineral water pipeline; data import from old maps and plans for existing WSS; analysis about range, content and quality of input geospatial data.

Partial land surveying measurements have been made at different times with different instruments in different coordinate systems.

Topologies of all necessary objects (see Tab. 1) are made.

\subsection{Database Connectivity}

When data structuring is ready, drawing layers are exported as SDF files. Thus, drawing objects are ready to be mapped to feature classes and converted to industry model (Figs. 4, 5).

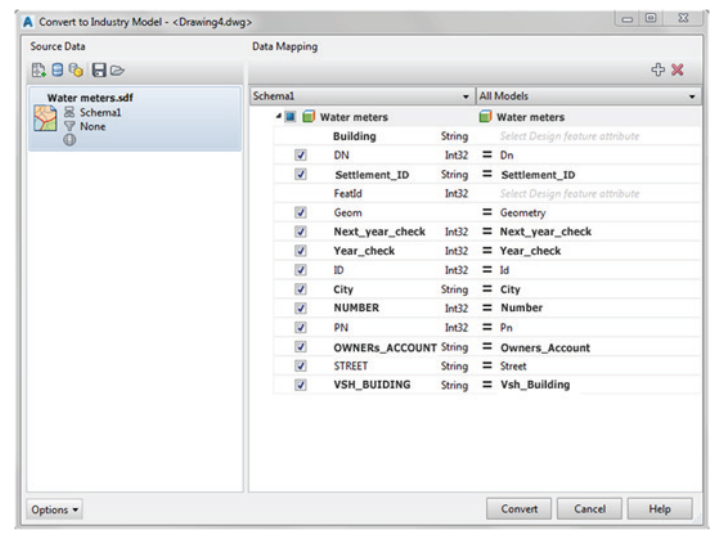

Fig. 4. Data mapping

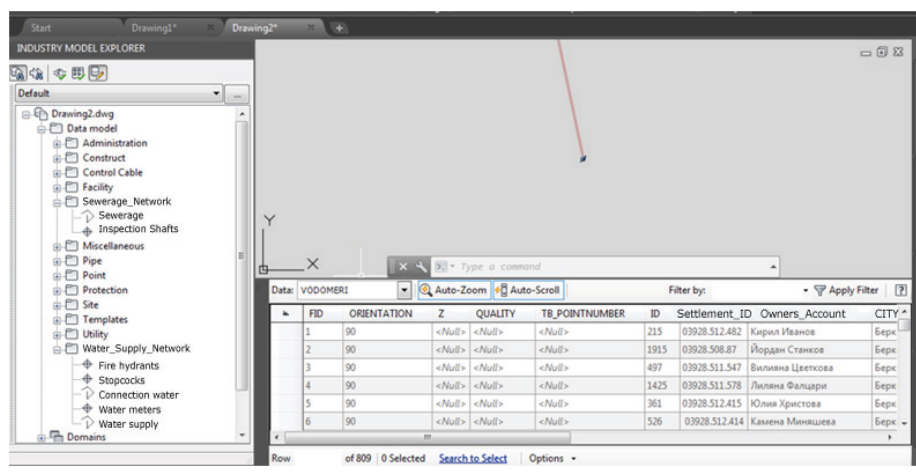

Fig. 5. Converted water meters to industrial model 
Database connectivity associates drawing objects with an external database (ODBC). When a database is connected to a project, Data View can be used to view, modify, sort and print selected records from the tables of that database. In order to establish a connection between drawing objects and a record in the database, a link between them must be generated. Link Template contains information about the linked database as well as values from the key field selected to define the connection.

For the current project, the links as follows were made:

- Point objects - water meters (Fig. 6a), stopcocks, hydrants and inspection shafts. The connection between the object and the record is made automatically by Generate Links option.

- Network objects - water supply (Fig. 6b), building deviations and sewerage, the connection between object and record is made using the Data View option, highlighting a record, selecting Link and pointing at the drawing object.

The linked database is shown at Figure 7.

a)

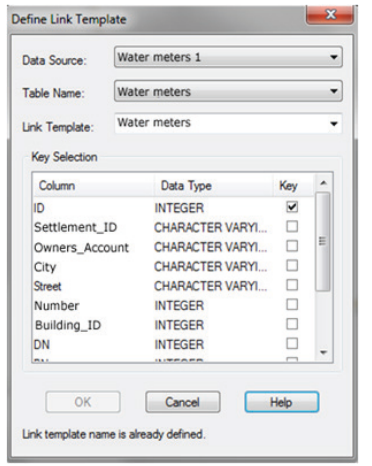

b)

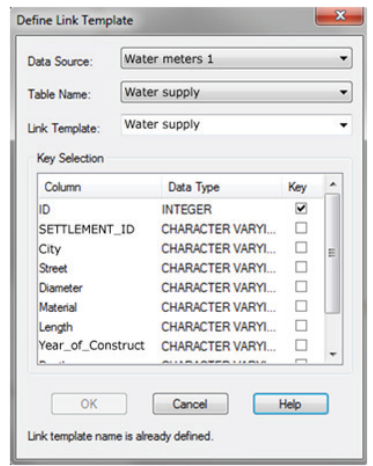

Fig. 6. Define Link Template: a) Water meter; b) Water supply

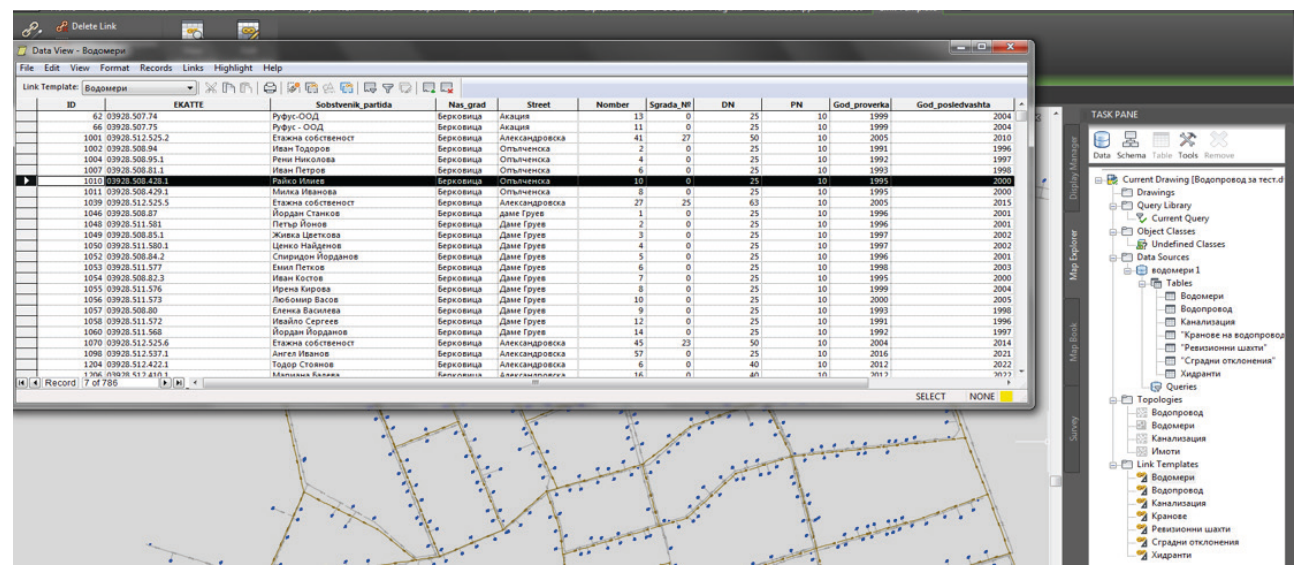

Fig. 7. Linked database 


\section{Conclusion}

The discussed topic deals with the essence of geoinformation systems. The possibility of combining the functionality of GIS and other systems for the support and maintenance of infrastructure networks for UUI is considered. The result is a geospatial model which functionality fully meets the specified requirements for the following: creation, maintenance (editing) and database storage, spatial and non-spatial information about model objects; generate standard reports; automated creation of cartographic products; performing spatial analyzes.

The implementation and usage of a geoinformation system for infrastructure networks will be a prerequisite for efficiency in the maintenance and management of WSS infrastructure.

It should be borne in mind that the design and implementation of any kind of information systems is a long and expensive process, so it is very important to keep the data and system up-to-date. This is also a prerequisite for the return of the initial investment by offering up-to-date services with data from the model.

The examined case does not completely exhaust the possibilities related to providing the necessary tools for model processing and maintenance, but it can be used as an example for the realization of an industrial model concept.

Later, WSS infrastructure data can be extended and implemented in 3D Cadastre [7], as proposed in [5]. The concept of using WSS infrastructure data as a subsystem of the 3D Cadastre using graphical methods of the object-oriented analysis. Modernisation and thematic expansion of cadastral databases is a chance to improve the real estate market.

\section{References}

[1] Ivanova I.: Otnovo za spetsializiranite karti. Minno-geolozhki universitet "Sveti Yoan Rilski”, Sofia 2008 [Иванова И.: Отново за спец̧иализираните карти. Минно-геоложки университет “Свети Йоан Рилски”, София 2008].

[2] Patel J., Sinha S.K.: Geographic Information System (GIS) Web-Based Water Pipeline Data Visualization for Decision Support. [in:] Heidrick J.W., Mihm M.S. (eds.), Pipelines 2019: Multidisciplinary Topic, Utility Engineering and Surveying, American Society of Civil Engineers, Reston 2019, pp. 95-103.

[3] Pavlov P.: Methods for spatial data storage and maintenance in RDBMS. [in:] 5th International Scientific Conference - SGEM2005, Conference Proceedings, 2005, pp. 693-704.

[4] Mika M., Siejka M., Leń P., Król Ż.: The concept of using the water cadastre databases components for the construction of multi-dimensional cadastre in Poland. Survey Review, vol. 50 (360), 2018, pp. 201-211. https://doi.org/10.1080/0039 6265.2016.1263180. 
[5] Szopińska K.: Creation of Theoretical Road Traffic Noise Model with the Help of GIS. [in:] Proceedings of the Environmental Engineering 10th International Conference Vilnius Gediminas Technical University, Vilnius, Lithuania, 27-28 April, pp. 1-8. https://doi.org/10.3846/enviro.2017.122.

[6] Siejka M., Ślusarski M., Zygmunt M.: 3D+time Cadastre, possibility of implementation in Poland. Survey Review, vol. 46 (335), 2014, pp. 79-89. https:// doi.org/10.1179/1752270613Y.0000000067.

[7] Geographic information - Land Administration Domain Model (LADM). ISO 19152:2012.

[8] Valchinov V., Aleksandrov B.: Kolichestven kontrol na surovini i materiali chrez geodezicheski metodi. Geomedia [Вълчинов В., Александров Б.: Количествен контрол на суровини и материали чрез геодезически методи. Геомедия], vol. 6, 2012, pp. 8-15.

[9] Kunchev I.: Geo-informatsionni aspekti na informatsionnoto modelirane v profesionalno napravlenie "Arhitektura, Stroitelstvo i Geodezia". Godishnik na Universiteta po Arhitektura, Stroitelstvo i Geodezia Sofia [Кунчев И.: Гео-информационни аспекти на информационното моделиране в професионално направление "Архитектура, Строителство и Геодезия”. Годишник на Университета по Архитектура, Строителство и Геодезия София], vol. 52, issue 2, 2019, pp. 669-680. 